\title{
Unexpected pulmonary nocardiosis in a non-immunocompromised patient
}

\author{
J M BRECHOT, F CAPRON, J PRUDENT, J ROCHEMAURE
}

From the Service de Pneumologie, Service central "Jacques Delarue" d'Anatomie et de Cytologie Pathologiques, and Service de Chirurgie, Hôtel Dieu, Paris

Pulmonary nocardiosis in a non-immunodeficient patient is rare and difficult to diagnose. We report a case of chronic pleuropulmonary disease for which the diagnosis of nocardial infection was suspected as a result of pathological examination of lung tissue after emergency lobectomy for massive haemoptysis.

\section{Case report}

A 46 year old man had sudden onset of fever $\left(39^{\circ} \mathrm{C}\right)$ and right thoracic pain. He was treated with ampicillin ( $6 \mathrm{~g}$ daily) for 48 hours before being referred to our hospital. Physical examination revealed a massive right pleural effusion. Aspirated fluid was cloudy and contained $85 \%$ polymorphonuclear leucocytes; direct bacterial examination and cultures gave negative results. Appearances at fibreoptic bronchoscopy were normal. Treatment with ampicillin was continued intravenously and repeated pleural lavage was

Address for reprint requests: Dr JM Brechot, service de Pneumologie, Hôtel Dieu de Paris, 1 place du Parvis Notre Dame, F 75181 Paris Cédex 04.

\section{Accepted 27 June 1986}

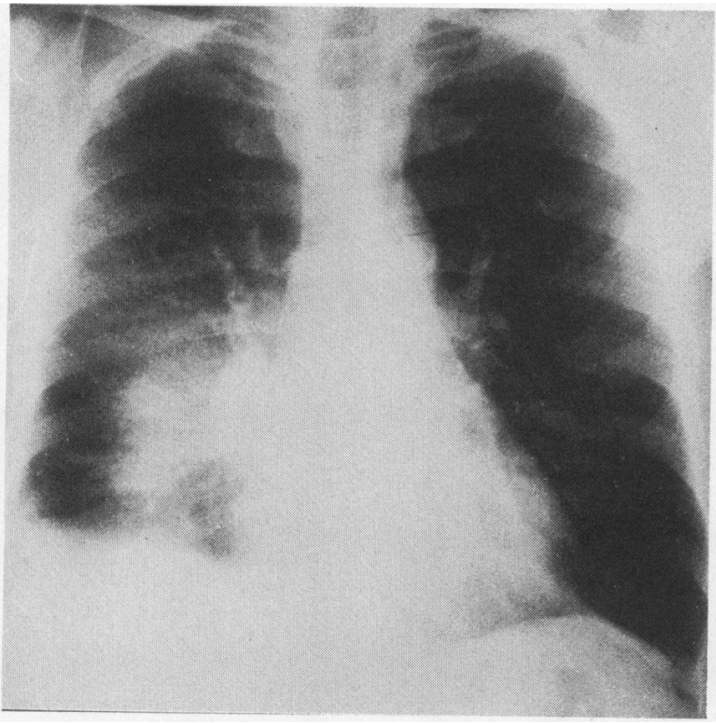

Fig 1 Chest radiograph three weeks after the start of treatment for right pleural effusion. carried out. He was discharged from hospital after clinical and radiological improvement. Three weeks later the patient was readmitted because of recurrence of fever $\left(39^{\circ} \mathrm{C}\right)$, cough, mucopurulent sputum, and a middle lobe infiltrate (fig 1). Blood cultures were negative. Appearances at fibreoptic bronchoscopy and results of bronchial aspiration were normal. Despite treatment with trimethoprim $(6 \mathrm{mg} / \mathrm{kg}$ body weight daily) and sulphamethoxazole ( $32 \mathrm{mg} / \mathrm{kg}$ daily) a massive haemoptysis of $500 \mathrm{ml}$ occurred; it was ascribed to the right bronchial tree. Bronchial arteriography showed an angiomatous appearance of the right intercostobronchial artery; this was considered to represent vascular hyperplasia due to chronic inflammation. Despite embolisation, haemoptysis recurred, necessitating a middle lobectomy with a wedge upper lobe resection. Pathological examination of removed material showed chronic pneumonia with suppurative areas, in which filamentous Gram positive and weakly Ziehl-Nielsen positive bacteria were present, sug-

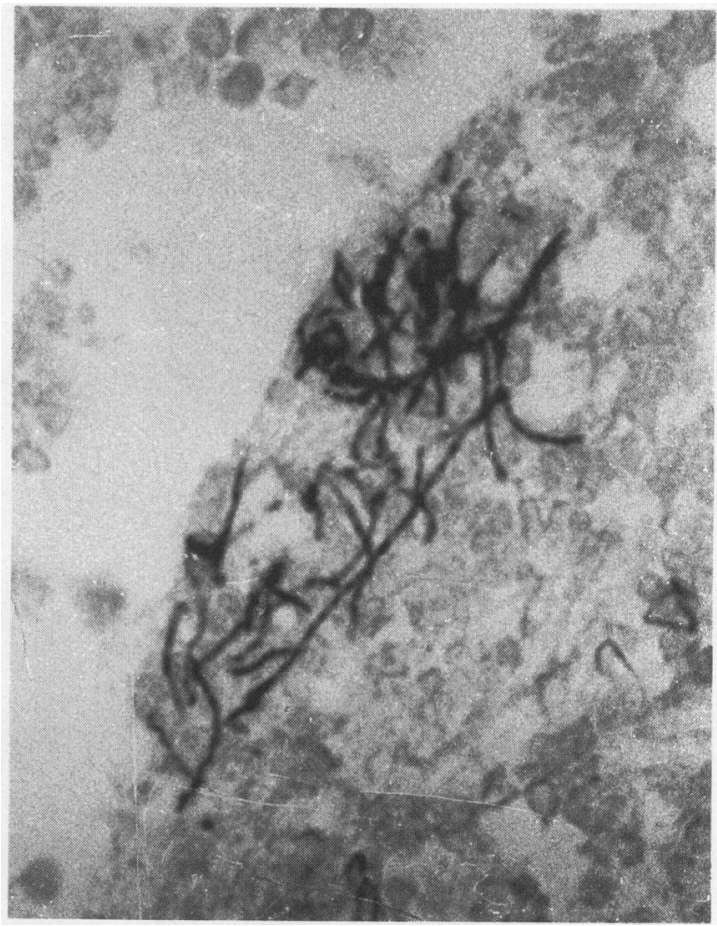

Fig 2 Section of lung tissue showing thin flamentous branched bacteria (Gomori's methenamine silver stain). 
gesting the diagnosis of nocardial pulmonary infection (fig 2). Serum precipitins against Nocardia asteroides were detected by electrosyneresis $(3,6$ lines of precipitation). There were no signs of extrathoracic extension; in particular, the computed tomographic scan of the brain was normal. Treatment with trimethoprim-sulphamethoxazole was continued during eight months and then stopped because of leucopenia; no recurrence occurred during this period.

\section{Discussion}

Although immunodeficiency (such as is observed with long term corticosteroid treatment) and chronic bronchopulmonary diseases are predisposing factors pointing to the possibility of nocardiosis, this may occur despite the absence of these risk factors. ${ }^{1-4}$ Our patient was a light smoker without chronic bronchitis; he had intermittent asthma with infrequent exacerbations and no history of corticosteroid treatment and so could not be included in the group at risk. Thus in this case the diagnosis was revealed only by careful microbiological examination of lung tissue. Surgery was necessary despite treatment with trimethoprim-sulpha- methoxazole, one of the most active drugs for this infec: tion. 5 The massive haemoptysis may be explained by thes? hypervascularisation commonly present at the site of chronic pulmonary inflammation. ${ }^{6}$

\section{References}

1 Frazier AR, Rosenow EC, Roberts GD. Nocardiosis: a review of 25 cases occurring during 24 months. Mayo Clin Pro? 1975;50:657-63.

2 Curry WA. Human nocardiosis: a clinical review with selectedw case reports. Arch Intern Med 1980;140:818-26. 3 Schlossberg D, Bronstein D, Jeffries R, Sams M. Pulmonary no 2

4 Lerner PI. Pneumonia due to Actinomyces, Arachnia, and No cardia. In: Pennington JE, ed. Respiratory infections: diagnosi and management. New York: Raven Press, 1983:387-96.

5 Smego RA, Moeller MB, Gallis HA. Trimethoprim-sulfa- $-\widehat{ }$ methoxazole therapy for Nocardia infections. Arch Intern MedO 1983;143:711-8.

6 Viau F, Grenier PH, Lecocguic Y, Pariente R. Hémoptysies: principales étiologies et conduite à tenir. In: Encyclopédie médicale et chirurgicale. Paris: Poumon, 1983: 6090 A10. 